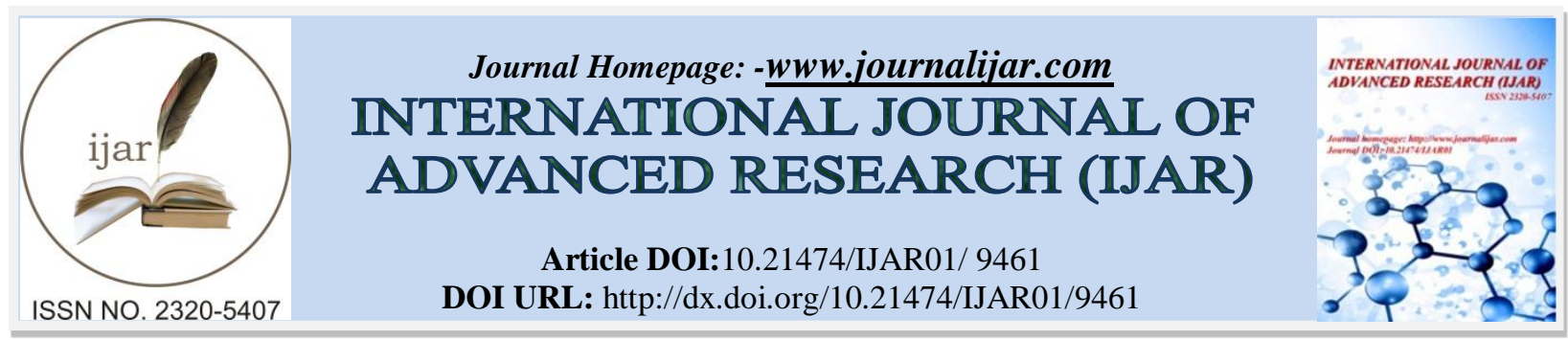

RESEARCH ARTICLE

\title{
JOB MOTIVATION AND SATISFACTION AMONG LOCAL GOVERNMENT PERSONNEL IN THE MUNICIPALITY OF SARA, PROVINCE OF ILOILO PHILIPPINES.
}

\section{Joey S. Dela Cruz.}

Sara, Iloilo, Philippines.

\section{Manuscript Info}

\section{Manuscript History}

Received: 27 May 2019

Final Accepted: 29 June 2019

Published: July 2019

Key words:-

Job motivation; job satisfaction; local government; public; management.

\section{Abstract}

The level of job motivation and satisfaction among local government personnel in the Municipality of Sara, Province of Iloilo Philippines during the year 2016-2017 as affected by the motivating factors incentive, fear, achievement, growth, power and social and satisfying factors satisfaction with coworkers, compensation, supervision/management, workload, professional opportunities, autonomy, policy/procedures, nature of work, control over practice, staffing/resources, work environment, promotion, scheduling, recognition, task variety, opportunities to interact with colleagues, access to information, predictability of job, and contingent benefits were determined. Employees perceived a very high level of job motivation from the motivating factors. Power and achievement gave the highest level of job motivation while the social factor gave the least motivation. Analysis of variance however showed no significant difference among the levels of motivation. The satisfying factors gave a very high level of satisfaction to the employees. Satisfaction with coworkers gave the highest level of satisfaction while the supervision/management and workload gave the least satisfaction to the respondents. Analysis of variance on the data showed that there was no significant difference on the effect of the factors tested to the job satisfaction of the employees. Positive correlation between job motivation and job satisfaction was found.

Copy Right, IJAR, 2019,. All rights reserved. 


\section{Introduction:-}

Human resource is the core of every organization. The people that form organizations are the ones who make it possible to achieve the organization's objectives and are the ones responsible to maintain its existence. Therefore the main goal of human resource management is to understand how it can retain its human resource and how it can enhance the performance of every employee, thus helping the organization grow and achieve its objectives (Maheswari, 2014).

Job performance and job satisfaction have been found to have a strong correlation. Studies show that employees are more effective when they are satisfied. This results to good customer relations, and customer satisfaction and loyalty (Almintisir, Akeel, \& Subramaniam, 2012). Satisfied employees also show a high level of commitment to the organization and express no desires to resign (James L. Perry, 2011). On the other hand when they are not satisfied, they tend to disappear from work, have lesser output, and do not follow the work standards (Almintisir et al., 2012).

Job satisfaction has been defined in literature as the employee's positive perception of his work, given the gains he gets from the work that are consistent with his needs (Brief and Weiss, 2001). It is also a measure of preference for the work compared to other occupational opportunities (Lèvy-Garboua, Montmarquette, and Simonnet, 2007). Błoński \& Jefmański (2013) further supports that it includes one's attitude while doing the work and one's behavior in reaction to the work environment.

Understanding employee satisfaction helps in building and adapting a management system suited to increase employee motivation (Błoński \& Jefmański, 2013). A lot of studies had been done on job satisfaction because of its paramount importance in the achievement of goals in an organization. Employees who are unsatisfied are less willing to do the job, less committed to the organization, and do not perform well (Almintisir et al., 2012). On the other hand, employees who are satisfied show an improvement in performance. Feelings of satisfaction appear when expectations about the work and the reality are consistent (Almintisir et al., 2012).

The most recognized theory on job satisfaction is Hertzberg's Two Factory Theory that categorizes the two types of needs of employees necessary for job satisfaction: hygiene and motivator. The hygiene factors relate to the basic needs of an employee at work and fulfilling these factors results to a neutral state, or ground zero, where the employee is neither satisfied nor dissatisfied. However when these needs are not met then the employees become dissatisfied. Examples of hygiene factors are salary, job security, benefits, supervision and working conditions. The motivators on the other hand are the factors that should be fulfilled on top of the hygiene factors in order to reach a high level job satisfaction. If the motivators are not provided, the employee's satisfaction remains in a neutral state. However if only the motivators are met and the hygiene factors are absent then this results again to dissatisfaction. Examples of motivators are the factors resulting from work payoff like, responsibility, authority or power, promotions and achievements (Almintisir et al., 2012.

One hygiene factor considered to affect job motivation in this study is incentive. Incentive may be given as an additional payment to employees as a way of increasing output. Research show that in the government few employees experience a good incentive and reward system compared to those in private companies (Almintisir et al., 2012). Improving the incentive and reward system in the government sector will increase the job satisfaction of the employees and thus increase their job performance, as these two were found to be positively correlated (Almintisir et al., 2012).

Achievement and fear may also affect job motivation and was included in this study. Fear is defined as a feeling of profound respect for someone or something while achievement is defined as the action of accomplishing something. According to studies people who choose a career in management especially in the public sector have a stronger need for achievement and are more invested to their work compared to those who work in private companies (Özbilgin et al., 2005, Guyot (1962).

The opportunity for growth and power may also be among the factors affecting job motivation. Employees who are satisfied with their jobs and who have established a reliable work experience have been shown to express their desire for empowerment (Maheswari, 2014). 
Social factors may also motivate government employees to perform better. It has been found that autonomy and group unity increase job satisfaction and create a positive atmosphere at work (Appelbaum and Kamal, 2000). According to Åteg et al., (2004) recognition of competence from the management and coworkers are also considered determinants of job satisfaction (Almintisir et al., 2012).

Aside from factors affecting job motivation, the factors affecting job satisfaction was also the focus of this study. Herzberg (2017) was reported to categorize the factors influencing job satisfaction into the physical environment, social and psychological factors (Yuxin \& Farooq, 2019). The environmental factors considered in this study are nature of work, policy/procedures, control over practice, staffing or resources, work environment, scheduling, task variety and access to information. The social factors considered are workload, opportunities to interact with colleagues, compensation, professional opportunities, promotion, recognition and contingent benefits. The psychological factors considered were satisfaction with coworkers, supervision/management, predictability of job and autonomy.

It is beneficial to analyze the factors that affect job satisfaction in employees to know the factors that increase their job performance and to improve the consistency of excellence in their performance (Yuxin \& Farooq, 2019).

\section{Statement of the Problem}

This study aimed to find out the job motivation and satisfaction among local government personnel in the Municipality of Sara, Province of Iloilo Philippines during the year 2016-2017.

Specifically, this study sought to answer the following questions:

What is the level of job motivation among the respondents in terms of:

1. Incentive;

2. Fear;

3. Achievement;

4. Growth;

5. Power; and

6. Social?

Is there a significant difference in the level of job motivation among the respondents in terms of:

1. Incentive

2. Fear;

3. Achievement;

4. Growth;

5. Power; and

6. Social?

What is the level of satisfaction of local government personnel in terms of:

1. Satisfaction with Coworkers;

2. Compensation;

3. Supervision/Management;

4. Workload;

5. Professional Opportunities;

6. Autonomy;

7. Policy/Procedures;

8. Nature Of Work;

9. Control Over Practice;

10. Staffing/Resources;

11. Work Environment;

12. Promotion;

13. Scheduling;

14. Recognition;

15. Task Variety;

16. Opportunities to Interact with Colleagues; 
17. Access to Information;

18. Predictability of Job; and

19. Contingent Benefits?

Is there significant difference on the level of satisfaction of local government personnel in terms of:

1. Compensation;

2. Supervision/Management;

3. Workload;

4. Professional Opportunities;

5. Autonomy;

6. Policy/Procedures;

7. Nature Of Work;

8. Control Over Practice;

9. Staffing/Resources;

10. Work Environment;

11. Promotion;

12. Scheduling;

13. Recognition;

14. Task Variety;

15. Opportunities to Interact with Colleagues;

16. Access to Information;

17. Predictability of Job; and

18. Contingent Benefits?

Is there a relationship between the level of job motivation and the level of job satisfaction of local government personnel?

\section{Methodology:-}

Factors that provide job motivation and job satisfaction in the local government of Sara were identified and data on employee perception of these factors, gathered through survey, was measured quantitatively using a standardized scale. Survey questionnaires were randomly distributed to 40 employees of the municipal hall of the local government of Sara. The respondents were asked to rate their level of job motivation in terms of six workplace factors (incentive, fear, achievement, growth, power and social) using a standardized five-point scale with 1.0-1.50 as poor, 1.51-2.50 as fair, 2.51- 3.50 as high, 3.51-4.50 as very high and 4.51-5.0 as excellent. The variance of the mean scores of these factors was determined to identify which factors had the greatest and the least impact on their level of job motivation. The level of their satisfaction on the 19 different workplace factors (satisfaction with coworkers, compensation, supervision/management, workload, professional opportunities, autonomy, policy/procedures, nature of work, control over practice, staffing/resources, work environment, promotion, scheduling, recognition, task variety, opportunities to interact with colleagues, access to information, predictability of job, and contingent benefits) were also rated on the same scale. The variance of their mean scores was also determined to identify which factors had the greatest and the least impact on their job satisfaction. Statistical analysis was carried out using One-Way ANOVA. Correlation between job satisfaction and job motivation was further analyzed using the Pearson Correlation Test.

\section{Results and Discussion:-}

The questionnaire gathered the perceived level of job motivation of the public employees from the six motivating factors tested in this study. The results presented in Table 1 show that the respondents received a very high level of motivation from incentive, fear, achievement, growth, power and social factors at work.

Table 1:-Mean scores of the level of job motivation of the respondents as affected by workplace factors

\begin{tabular}{|l|l|c|c|c|}
\hline & Motivating Factor & Mean & Description & SD \\
\hline & Incentive & 4.17 & Very high & .643 \\
\hline & Fear & 4.17 & Very high & .640 \\
\hline & Achievement & 4.19 & Very high & .623 \\
\hline Growth & 4.17 & Very high & .624 \\
\hline
\end{tabular}




\begin{tabular}{|l|l|l|l|l|}
\hline & Power & 4.19 & Very high & .579 \\
\hline Social & 4.13 & Very high & .626 \\
\hline & General Mean & $\mathbf{4 . 1 7}$ & Very high & $\mathbf{. 6 4 1}$ \\
\hline
\end{tabular}

Figure 1 shows that among the factors tested, power and achievement gave the employees in the local government of Sara the highest level of job motivation. The least factor to affect their job motivation was the social factor. It can also be observed that the mean scores have very close values and have very low standard deviation from each other.

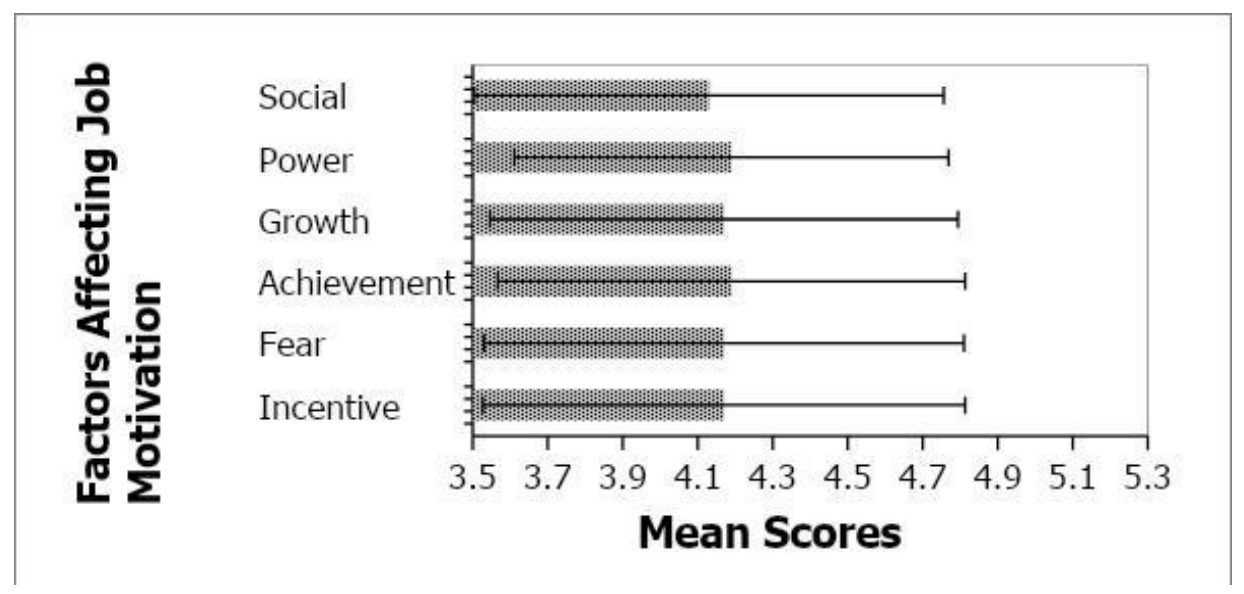

Fig 1:-Mean scores and standard deviation of the level of job motivation of the respondents as affected by workplace factors

In the private sector managers implement policies and reward systems to motivate higher employee performance while those who work in the public sector may find that they have less opportunity for rewards and that they cannot easily change their working conditions through better performance (Ng, Gossett, Chinyoka, \& Obasi, 2016). Aside from that, the numerous procedural obstacles and equivocal goals in the public sector may discourage employees' public service motivation. Thus those who stay working in the government may become motivated by the possibility of power and influence that can surpass these hassles (Taylor, 2008).

Social factors are referred to as the disposition and relationship of employees at work with their co-workers, their participation, acknowledgement, and workload (Yuxin

Farooq, 2019). As the management have a greater capacity, power and influence to affect employee's jobs more than their workmates, e.g. allow more autonomy, it is possible that the management would have more influence over employee motivation more than their relations with their co-workers (Taylor, 2008). This may explain why the respondents gave the social factor the least score for job motivation.

However, regardless of the rankings Table 2 shows that the mean scores of all the factors tested had no significant difference from each other. This implies that employees perceive that they are motivated at the same level by incentive, fear, achievement, growth, power and social factors in the workplace. These factors may also work together to motivate the employees.

Table 2:-The difference in the level of job motivation among the respondents as affected by workplace factors

\begin{tabular}{|l|l|r|r|c|}
\hline & Motivating Factor & F-Value P-Value Decision & \multicolumn{2}{l|}{ Accept Ho } \\
\hline & Incentive & .242 & .914 & Accept Ho \\
\hline & Fear & .251 & .909 & Accept Ho \\
\hline & Achievement & .265 & .900 & Accept Ho \\
\hline & Growth & .322 & .863 & Accept Ho \\
\hline & Power & .582 & .677 & Accept Ho \\
\hline & Social & .153 & .961 & \\
\hline
\end{tabular}


The response of the public employees to the 19 elements that affect their job satisfaction was also gathered. The results show that the factors in the local government workplace in Sara such as satisfaction with co-workers, compensation,supervision/management, workload, professional opportunities, autonomy, policy/procedures, nature of work, control over practice, staffing/resources, work environment, promotion, scheduling, recognition, task variety, opportunities to interact with colleagues, access to information, predictability of job, and contingent benefits gave very high satisfaction to the employees, as can be seen in Table 3.

Table 3:-Mean scores of the level of job satisfaction of the respondents as affected by workplace factors

\begin{tabular}{|c|c|c|c|}
\hline Satisfying Factor & Mean & Description & SD \\
\hline Satisfaction with Co-workers & 4.26 & Very high & .577 \\
\hline Compensation & 4.21 & Very high & .521 \\
\hline Supervision/Management & 4.16 & Very high & .627 \\
\hline Workload & 4.16 & Very high & .607 \\
\hline Professional Opportunities & 4.17 & Very high & 607 \\
\hline Autonomy & 4.18 & Very high & 616 \\
\hline Policy/Procedures & 4.19 & Very high & .623 \\
\hline Nature of Work & 4.24 & Very high & .339 \\
\hline Control Over Practice & 4.22 & Very high & .321 \\
\hline Staffing/Resources & 4.20 & Very high & .605 \\
\hline Work Environment & 4.24 & Very high & .464 \\
\hline Promotion & 4.21 & Very high & .495 \\
\hline Scheduling & 4.20 & Very high & .483 \\
\hline Recognition & 4.20 & Very high & .481 \\
\hline Task Variety & 4.20 & Very high & .476 \\
\hline Opportunities to Interact with Colleagues Regarding & 4.20 & Very high & .479 \\
\hline Patient Care & & & \\
\hline Access to Information & 4.22 & Very high & .326 \\
\hline Predictability of Job & 4.24 & Very high & .464 \\
\hline Contingent Benefits & 4.19 & Very high & .623 \\
\hline General Mean & 4.20 & Very High & .480 \\
\hline
\end{tabular}

Satisfaction with co-workers gave the highest level of satisfaction followed in the same ranking by the nature of work, work environment and the predictability of the job. Supervision/Management and workload both gave the least level of job satisfaction to the respondents as can be seen in Figure 2.

According to Moynihan and Pandey (2007) a public organization is a structured environment where employees engage, relate and affect each other. The complex system of organizations allows employees to depend on each other for accomplishment of their roles. A supportive and harmonious working environment allows employees to fulfill their roles and their job satisfaction is more influenced by social cues than by their job descriptions (Taylor, 2008).

The high satisfaction from relations with co-workers as seen in this study can be due to the satisfaction and ease in the delivery of services experienced when employees unite and work well together. Examples of some of these attitude appreciated by employees according to Błoński \& Jefmański (2013) are timely and reliable delivery of errands between co-workers, readiness to help other co-workers, avoiding gossip, relating and communicating well to co-workers and appropriating skills and credentials to offered positions. 


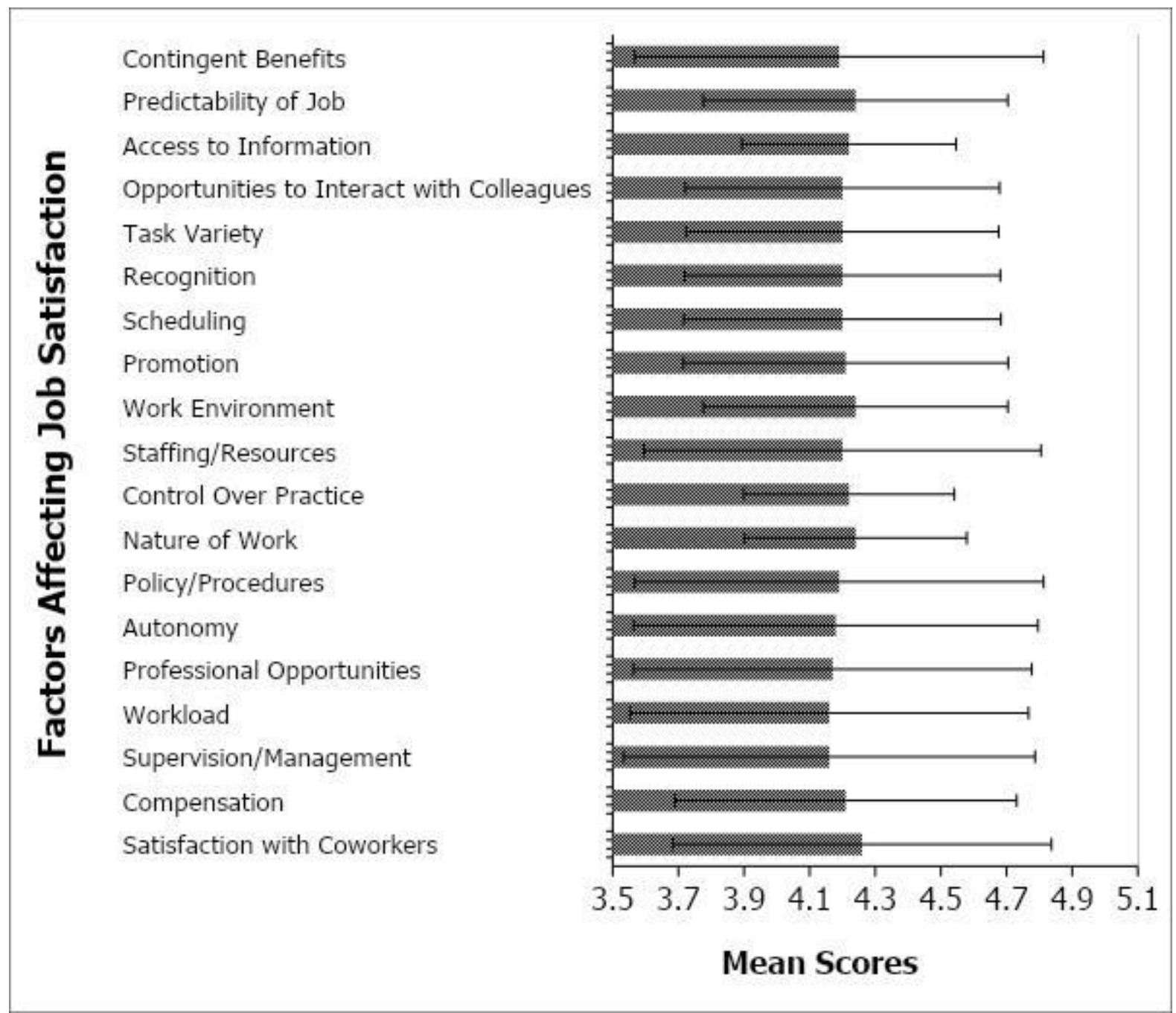

Fig 2:-Mean scores and standard deviation of the factors affecting the job satisfaction of the respondents

On the other hand supervision/management and workload provided the least satisfaction may be due to some expectations from management that may have not been met and may be due to a lot of workload in the office. According to Błoński \& Jefmański (2013) cooperation between employee and supervisor would show effective communication between superior and employee, clear orders, and willingness to help from the supervisor. Lower levels of satisfaction according to Rainey and Bozeman (2000) can also be due to the restrictions caused by bureaucracy (Błoński \& Jefmański, 2013).

Another reason may be that employees perceive that the managers are not qualified. According to Almintisir et al. (2012) only $10.6 \%$ of the government employees in their study agreed that their managers were selected based on qualification and experience. It is necessary to hire qualified managers otherwise it will cost the company to retrain them or let them go, which is costlier than hiring excellent managers (Almintisir et al., 2012).

There was a low standard deviation among the scores, however, and analysis of variance on the data as presented in Table 4 show that there was no significant difference on the effect of the factors tested to the job satisfaction of the employees. This implies that satisfaction with co-workers, compensation, supervision/management, workload, professional opportunities, autonomy, policy/procedures, nature of work, control over practice, staffing/resources, work environment, promotion, scheduling, recognition, task variety, opportunities to interact with colleagues, access to information, predictability of job, and contingent benefits all had the same effect on the job satisfaction of the respondents and must have a correlation with each other. 
Table 4:-Difference on the level of satisfaction of local government personnel as affected by workplace factors

\begin{tabular}{|l|l|c|c|c|}
\hline \multicolumn{1}{|c|}{ Satisfaction } & \multicolumn{2}{c|}{ F-Value P-Value Decision } \\
\hline & & & & \\
\hline & Satisfaction with Co-workers & .023 & .999 & Accept Ho \\
\hline & Compensation & .198 & .939 & Accept Ho \\
\hline & Supervision/Management & .085 & .987 & Accept Ho \\
\hline & Workload & .112 & .978 & Accept Ho \\
\hline & Professional Opportunities & .112 & .978 & Accept Ho \\
\hline & Autonomy & .105 & .981 & Accept Ho \\
\hline & Policy/Procedures & .105 & .980 & Accept Ho \\
\hline & Nature of Work & .844 & .501 & Accept Ho \\
\hline & Control Over Practice & 1.044 & .390 & Accept Ho \\
\hline & Staffing/Resources & .402 & .806 & Accept Ho \\
\hline & Work Environment & .176 & .950 & Accept Ho \\
\hline & Promotion & .410 & .801 & Accept Ho \\
\hline & Scheduling & .394 & .812 & Accept Ho \\
\hline & Recognition & .354 & .840 & Accept Ho \\
\hline & Task Variety & .239 & .916 & Accept Ho \\
\hline & Opportunities to Interact with Colleagues & .221 & .926 & Accept Ho \\
\hline & Access to Information & .257 & .905 & Accept Ho \\
\hline & Predictability of Job & .197 & .938 & Accept Ho \\
\hline & Contingent Benefits & .024 & .999 & Accept Ho \\
\hline & & & \\
\hline
\end{tabular}

The relationship between job motivation and job satisfaction was further analyzed and it showed that there was a positive correlation between the job motivation and job satisfaction of the respondents. This means that when the job motivation is high, the job satisfaction is also high. This implies that increasing the job motivation of employees may also increase their job satisfaction, or increasing their job satisfaction may also increase their job motivation.

Table 5:-The relationship between the job motivation and satisfaction of local government personnel

\begin{tabular}{|l|c|c|c|c|c|}
\hline & Compared Variables & & Satisfaction & Description & Decision \\
\hline & Motivation & Pearson Correlation & $.380^{* *}$ & Positive & Reject Ho \\
\hline & & Significance(2-tailed) & .000 & & \\
\hline & & & & & \\
\hline
\end{tabular}

\section{Conclusion and Recommendation:-}

Employees perceived a very high level of job motivation from the motivating factors. Power and achievement gave the highest level of job motivation while the social factor gave the least motivation, but there was no significant difference among the levels of motivation. The satisfying factors gave a very high level of satisfaction to the employees. Satisfaction with co-workers gave the highest level of satisfaction while the supervision/management and workload gave the least satisfaction to the respondents, though there was no significant difference found. There was positive correlation between job motivation and job satisfaction. When the job motivation is high, the job satisfaction is also high.

It is recommended for further studies that feedback from respondents be gathered and reasons for the scores be further elucidated. 


\section{References:-}

1. Almintisir, A. B., Akeel, A. B., \& Subramaniam, I. D. (2012). Comparison of Job Satisfaction of Employees in Public and Private Sector Organizations: Evidence from Two Libyan Companies. Australian Journal of Basic and Applied Sciences, 6(8), 177- 186.

2. Appelbaum, S.H., \& Kamal, R. (2000). An Analysis of the Utilization and Effectiveness of Non-financial Incentives in Small Business. Journal of Management Development., 19(9), 733-763.

3. Błoński, K., \& Jefmański, B. (2013). Determinants of Satisfaction of the Employees of Local Government Units. Economics \& Sociology, 6(2), 158-170. Retrieved from DOI: 10.14254/2071-789X.2013/6-2/14

4. Brief, A. P., \& Weiss, H. M. (2001). Organizational behavior: affect in the workplace, Annual Review of Psychology, No. 53.

5. Guyot, J.F. (1962). "Government bureaucrats are different". Public Administration Review. 22 (4), 195-202.

6. Herzberg, F., Mausner, B., \& Snyderman B.B. (1959). The Motivation to Work. John Wiley:New York.

7. Kumar, N., \& Pankaj, G. (2011). Impact of motivational factors on employee's job satisfaction- A study on some selected organization in Punjab, India. Asian Journal of Management Research, 2(1), 672-683.

8. Lèvy-Garboua, L., Montmarquette, C., Simonnet, V. (2007). Job satisfaction and quits, Journal of SocioEconomics, Vol. 33.

9. Maheswari, M. U. (2014). Job Satisfaction of Municipal Government Employees with Particular Reference to Padmanabhapuram Municipality. Indian Journal of Commerce \& Management Studies, 5(1), 91-97.

10. Ng, E. S.W., Gossett, C. W., Chinyoka, S., \& Obasi, I. (2016). Public vs private sector employment: An exploratory study of career choice among graduate management students in Botswana. Personnel Review, 45(6), 1367-1385. Retrieved from 10.1108/PR-10-2014-0241

11. Özbilgin, M., Kusku, F. and Erdogmus, N. (2005). Explaining influences on career 'choice': the case of MBA students in comparative perspective. The International Journal of Human Resource Management. 16(11), 20002028.

12. Taylor, J. (2008). Organizational Influences, Public Service Motivation and Work Outcomes: An Australian Study. International Public Management Journal, 11(1), 67-88.

13. Yuxin, W., \& Farooq, M. (2019). Conceptual Framework Development for Job Satisfaction in Fujian Banking Industry, China. International Journal of Human Resource Studies, 9(1).Satisfaction with Coworkers. 